of determinism " therefore depends on the recognition of electrons as bodies co-equal with ordinary physical objects. To establish this he claims that since physical objects, as well as electrons and such particles, are all 'inferences', they differ only in degree and not in kind. We must not, however, be deceived by words. Objects which we see and handle may be, as he says, as inferential as an undiscovered planet inferred from irregularities in the motion of Uranus, but the inferences are of different kinds; otherwise, why, when a planet was seen in a different position from that inferred from the irregularities, was it without question preferred to the "undiscovered" inferential planet? There was not even an instinctive estimate of the 'degree' of validity to be attributed to the two 'inferences'. Unless Sir Arthur assigns to "direct observation" a status essentially different from that of rational deduction, it is difficult to see how his position can be " in no sense an abdication of scientific method". All this, however, does not affect determinism in relation to physical objects, and it is to be hoped that Sir Arthur's plain statement will do much to remove the widespread delusion that modern physics has revealed a universe of unrestrained caprice.

\section{Centenary of Octave Chanute}

ON Feb. 18 occurs the centenary of the birth of the distinguished American engineer Octave Chanute, who by his experiments on gliding made in his later years, and by his writings on flight, gained for himself a place among the chief pioneers of aviation. Born in Paris on Feb. 18, 1832, he was the son of a professor of history who in 1838 removed to the Urited States to become a vice-president of the Jefferson College in Louisiana. There and in New York young Chanute attended school and, in his own words, became thoroughly Americanised. Leaving school at the age of seventeen, he entered the service of the Hudson River Railroad Company, and during the next four years gained considerable engineering experience. He next spent ten years on various railroads farther west, and from 1863 until 1867 was chief engineer of the Chicago and Alton Railroad. In 1868 he built the first bridge over the Missouri at Kansas City, in 1873 became chief engineer of the Eric Railroad, and about ten years later established himself as a consulting engineer in Kansas. He had already served on the commission of engineers which led to the building of the elevated railways of New York, and at Kansas he was responsible for the construction of the Sibley Bridge over the Missouri, and for the Mississippi Bridge at Fort Madison, Indiana. He retired to Chicago in $\mathbf{1 8 8 9}$ after some forty years' work, much of which had contributed to making the railway system of the United States the most extensive in the world.

Chanute's interest in flight was first axoused in 1874, but it was not until he was nearly sixty years of age that he was able to devote himself wholeheartedly to the study of the subject. In 1891 he published his first work, "Aerial Navigation ", and this was followed in 1894 by his " Progress in Flying Machines", a work of great historical value. $\mathrm{He}$ had carefully examined the results of the experiments made by Otto Lilienthal in Germany, and just before that pioneer's death in 1896 had secured a Lilienthal glider and had begun his own experiments on the $90 \mathrm{ft}$. sand-hills in Dune Park, near Lake Michigan. Finding the Lilienthal machine unsafe and treacherous, Chanute built a glider with five superimposed planes, which was afterwards altered to a quadruplane and then to a triplane. From these was evolved " the famous Chanute biplane of novel and exquisite design". One important feature introduced by Chanute was the means of moving the wings in a fore and aft direction to maintain balance, thus obviating the necessity for violent body movements. The experiments begun in June 1896 were continued until September, but after then were never resumed. An account of them was given in a paper published in the Journal of the Society of Western Engineers in 1897. While abandoning experiments, Chanute, although then sixty-four years of age, retained his enthusiasm for everything connected with flight, assisted and encouraged Wilbur and Orville Wright, and when an old man wrote his "Recent Progress in Aviation". He died at Chicago on Nov. 23, 1910, at the age of seventy-eight. Chanute possessed the truly scientific spirit, and was an acute observer as well as a gifted inventor. Courageous and generous, his character caused him to be both respected and honoured.

\section{The Earthquake in Cuba}

ON Feb. 3 a series of destructive earthquakes, beginning at 2.40 A.M., ruined about one-third of the city of Santiago, at the east end of Cuba, including the cathedral and many important buildings. The number of persons killed is reported as twelve, and the number of wounded as about three hundred. The earthquake was recorded at Kew Observatory as a disturbance of moderate intensity. The first impulses arrived at 6h. 26m. 45s. A.M. (G.M.T.), and the earthquake must have occurred at $6 \mathrm{~h}$. $16 \mathrm{~m}$. The neighbourhood of Santiago has long been known as one of the most active earthquake centres in the West Indies. The city was founded in 1514, and since then there have been great destructive earthquakes in $1624,1678,1766$ (the greatest of all Cuban earth quakes), and 1852. Though the full extent of the damage is not yet known, the recent earthquake was probably of the second order of intensity among destructive earthquakes. The Santiago earthquakes are chiefly interesting owing to the position of their centres along a well-known dislocation, nearly 1250 miles long, that skirts the southern coast of the east end of the island and forms the northern boundary of the Bartlett Trough, a depression that in one part reaches a depth of 3506 fathoms, or about four miles.

\section{An Ancient Mexican Tomb}

A VALUABLE addition to our knowledge of a littleknown culture of ancient Mexico, that of the Mixtec, is promised by a recent find of which news has reached New York. In a dispatch from the Times' correspondent which appears in the issue of Jan. 20, 